African Crop Science Journal by African Crop Science Society is licensed under a Creative Commons Attribution 3.0 Uganda License. Based on a work at www.ajol.info/ and www.bioline.org.br/cs DOI: https://dx.doi.org/10.4314/acsj.v27i4.10

\title{
GIS-BASED MULTI-CRITERIA LAND SUITABILITY MAPPING FOR SCALING FABA BEAN VARIETIES IN ETHIOPIA
}

\author{
D. NIGUSSIE, W. MULUGETA, A. MOLLA ${ }^{1}$, Z. BISHAW ${ }^{2}$ and C. BIRADAR ${ }^{3}$
}

Ethiopian Institute of Agricultural Research, P. O. Box 2003, Addis Abeba, Ethiopia

${ }^{1}$ International Center for Agricultural Research in the Dry Areas, Addis Abeba, Ethiopia (currently in Debre Birhan Agricultural Research Center, Debre Birhan, Ethiopia)

${ }^{2}$ International Center for Agricultural Research in the Dry Areas, P. O. Box 5689, Addis Abeba, Ethiopia

${ }^{3}$ International Center for Agricultural Research in the Dry Areas, Maadi, Cairo, Egypt Corresponding author: wendafrash@gmail.com

(Received 27 September 2019; accepted 25 November 2019)

\begin{abstract}
Successful scaling of agricultural technology requires a spatial explicit framework for targeting the right variety at the right place. This entails a multi-criteria evaluation (MCE) approach, using a set of determining factors to delineate the scaling domains for faba bean (Vicia faba L.) varieties in and identify potentially suitable land area in a specific region, and zone in Ethiopia. Meeting this challenge will require a solid spatial framework. Land suitability analysis is an evaluation and spatial decision making, involving several determining factors. The factors considered in this analysis include key biophysical parameters such as climate, topography, soil types and properties. The analysis was also focused on improved faba bean varieties viz., Dagm, Dosha, Gabelcho, Gora, Hachalu, Moti and Walki. The environmental factors' layers of a specific crop pixel values were classified and given a weight, and then compared among themselves for further ranking to account for their relative importance to delineate variety specific extrapolation domains. The geo-statistical analysis was carried out to estimate the extent of the scalable areas. The classification showed that, it was highly suitable for varieties 0.02 million hectares for Dosha; 0.19 for Gabelcho; 0.11 for Gora; 0.33 for Moti; 0.05 for Dagm; 0.14 for Hachalu; and 0.26 million hectares for Walki. Moderately suitable areas for these varieties covered 5.0, $9.4,7.2,15.3,4.6,8.8$, and 7.5 million hectares, respectively across the country. The largest proportion for all varieties was moderately suitable; while the share of slightly suitable was very low, although there was quite variability within each of the faba bean variety in terms of its agro-ecology adaptation to the target environments. Such biophysical spatial frameworks become essential entry points for introducing variety specific product profiles and this can be further enhanced by incorporating socioeconomic attributes accounting for return of the investment in targeting the technology.
\end{abstract}

Key Words: Environmental factors, spatial decision 
La mise à l'échelle réussie de la technologie agricole nécessite un cadre d'explicite spatial pour se concentrer sur la bonne variété au bon endroit. Cela implique une approche d'évaluation multicritère (ECM), utilisant un ensemble de facteurs déterminants pour délimiter les domaines de mesurage pour les variétés de féverole (Vicia faba L.) et identifier les terres potentiellement appropriées dans une région et une zone spécifiques en Éthiopie. Relever ce défi exigera un cadre spatial certain. L'analyse de l'aptitude des terres est une évaluation et une prise de décision spatiale impliquant plusieurs facteurs déterminants. Les facteurs pris en compte dans cette analyse incluent des paramètres biophysiques clés tels que le climat, la topographie, les types de sol et leurs propriétés. L'analyse a également porté sur les variétés améliorées de féverole, à savoir Dagm, Dosha, Gabelcho, Gora, Hachalu, Moti et Walki. Les couches de facteurs environnementaux d'une valeur de pixel de plante spécifique ont été classifiées et pondérées, puis comparées entre elles pour un classement ultérieur tenant compte de leur importance relative dans la délimitation de domaines d'extrapolation spécifiques à une variété. L'analyse géo-statistique a été réalisée pour estimer l'étendue des zones évolutives. La classification a montré qu'elle convenait parfaitement aux variétés 0,02 million d'hectares pour Dosha; 0,19 pour Gabelcho; 0,11 pour Gora; 0,33 pour Moti; 0,05 pour Dagm; 0,14 pour Hachalu; et 0,26 million d'hectares pour Walki. Les zones moyennement adaptées à ces variétés couvraient respectivement 5,$0 ; 9,4 ; 7,2 ; 15,3 ; 4,6 ; 8,8$ et 7,5 millions d'hectares dans l'ensemble du pays. La plus grande proportion de toutes les variétés était modérément appropriée; alors que la proportion de produits légèrement appropriés était très faible, bien qu'il y ait une assez grande variabilité au sein de chaque variété de féverole en ce qui concerne son adaptation agroécologique aux environnements cibles. De tels cadres spatiaux biophysiques deviennent des points d'entrée essentiels pour l'introduction de profils de produits spécifiques à une variété, ce qui peut être encore amélioré en incorporant des attributs socioéconomiques permettant de rentabiliser l'investissement dans la focalisation de la technologie.

Mots Clés: Facteurs environnementaux, décision spatiale

\section{INTRODUCTION}

Ethiopia is characterised by diverse agroecologies that sustain its agricultural production and maintain its rich biodiversity. The existence of diverse farming systems, agro-ecologies, socio-economic, as well as cultural diversity have endowed the country with a biological wealth of species diversity, particularly the agro- biodiversity (IBC, 2007). Faba bean (Vicia faba L.) is one of the important legume crops in the highlands of Ethiopia, and secondary centres of diversity are postulated in Afghanistan and Ethiopia (Hawtin and Hebblethwaite, 1983). Ethiopia is also one of the major faba bean producing countries in the world, next to China (Tafere et al., 2012; Ermias and Addisu, 2013).
According to FAO (2019), the area harvested for faba bean increased from 298,490 ha in 1993 to 427,697 ha in 2016, with an increase in production from 312,405 to 878,010 metric tonnes, with corresponding productivity increase from 1.05 to 2.05 tonnes ha $^{-1}$ (Figure 1). This shows an increment of 43.3, 181.1 and $96.15 \%$ in area harvested, production and productivity, respectively.

Faba bean yields are low in Ethiopia due to biotic stresses such as foliar diseases (chocolate spot, rust, aschocyhta blight, faba bean leaf gall) (Dereje et al., 2012; Abebe et al., 2017), root diseases (black root rot), insect pests (aphids, pod borer), parasitic weeds (Orobanche crenata) and abiotic stresses (soil acidity, waterlogging, drought, and frost). 
Geographic Information Systems (GIS) enables a large amount of different geospatial and associated information to be assembled, combined, overlaid, modeled and mapped. With its huge capability, GIS can be a powerful tool in agricultural planning of an area for land use suitability. Therefore, GIS has contributed to the speed and efficiency of the overall planning process in agricultural land use suitability, since it enables quick and efficient access to large amounts of information, exhibiting relationships, patterns, and trends that are useful in monitoring land use potential and suitability evaluation (Singha and Swain, 2016). It is a useful tool for scaling proven technologies and packages of practices, including specific crops and crop varieties to address yield and nutritional gaps (Singha and Swain, 2016; Low et al., 2018).

To assist crop technology targeting and scaling-up, the potential of different land for different purposes should be identified so as to be allocated for appropriate use. Crops/ varieties should be selected based on different objectives addressing quality preferences such as adaptability, yield, tolerance to abiotic and biotic stresses, and market and nutritional values. Land suitability analysis work enables identification of where and how much potentially suitable land for a crop and crop variety exists in a specific location or in the country at large (Mokarram et al., 2010).

It is, therefore, important to map the agricultural land to show the extent and distribution of areas that are potentially suitable for a crop variety. It was within this context that this study was done, to gather and organise various data sets relevant to environmental requirements of the selected varieties; and analyse and depict the land suitability class of faba in Ethiopia.

Therefore, the objective of the study was to provide information on the choice of faba bean varieties based on crop variety suitability map where to be grown under optimum conditions in the target environments for enhancing faba bean production in Ethiopia.

\section{MATERIALS AND METHODS}

Interoperable spatial data layers were prepared to carry out multi-criteria land suitability evaluation. A set of interoperable spatial data layers of various biophysical (e.g. soils, topography and climatic) parameters were prepared to carry out multi-criteria suitability mapping. Key controlling factors were the bioclimatic variables, which vary in time and space. The plant growth parameters such as rainfall and temperature during the growing period and length of growing period (LGP), topography (digital elevation models. i.e. altitude and slope), soil types and soil chemical(PH) and physical properties (depth, texture, and drainage) were used in the AHP analysis to determine the suitable criteria. Park and lake areas were excluded (restricted) in this land suitability analysis. Administrative boundaries and infrastructure (roads, towns, and other facilities) were also used to prepare the final map and generate the tabular data.

The soil data used included soil properties and soil types, which were acquired from two sources. The soil properties were extracted from the Soil and Terrain Database of East Africa and gridded soil database of $250 \mathrm{~m}$ (ISRIC, 2015), while the soil type used was from MoA modified by the Woody Biomass Inventory and Strategic Planning Project (WBISPP, 2004). For the altitude information, the Shuttle Radar Topography Mission (SRTM) 90 m digital elevation model (DEM) database (Jarvis et al., 2008) was used and the same DEM used for topographic analysis such as generating slope maps. These data were resampled to a common spatial resolution of $200 \mathrm{~m}$ for the spatial analysis in the GIS domain.

Crop variety requirement. The faba bean varieties environmental requirement was generated based on product profiles (MoARD, 2006; MoARD, 2008; MoARD, 2009; MoA, 2010), literature review (Jarso and Keneni, 2006), expert consultations and from national 
variety trials conducted in multi-location and years that submitted for variety release in Ethiopia. The land evaluations study conducted by FAO $(1984 ; 2007)$ and by Sys et al. (1993) were used as a general guide to derive thresholds for defining the suitability categories. Stratification was made in terms of suitability, and were set as $S_{1}$ (very suitable), $\mathrm{S}_{2}$ (moderately suitable), and $\mathrm{S}_{3}$ (marginally suitable) and $N$ (unsuitable) based on the assumption indicated in the FAO land suitability classification structure (Table 1). According to FAO classification, $S_{1}$ corresponds to 85$100 \%, \mathrm{~S}_{2}$ to $60-85 \%, \mathrm{~S}_{3}$ to $40-60 \%, \mathrm{~N}_{1}$ to 25 $-40 \%$ and $\mathrm{N}_{2}$ to $25-0 \%$ (Elsheikh and Abdalla, 2016) of optimum yield under the recommended management practices.

Since the analysis is raster (pixel) based, some of the data, which were in vector format (object based), were converted to uniform raster datasets using polygon-to-raster conversion tool in ArcGIS. The important GIS layers of environmental factors affecting the growth of faba bean varieties were identified and each layer's pixel values classified and assigned weight. Then the environmental factor layers were compared among themselves and ranked using weighted overlay analysis developed under the ModelBuilder. Based on the rate and rank assigned to each pixel, the land suitability map for each variety was computed using weighted overlay analysis. The classification of each layer into suitability categories was done using Re class by Table function in ArcGIS spatial analyst (ESRI GIS package) tool. The reclassification is implemented in the model by preparing separate tables for each factor/criteria layer and faba bean variety.

Assigning criterion weights for overall suitability analysis. The overall suitability map is the combined result of the altitude, slope, soil types and soil properties, and the climate layers. The weighted overlay approach built on ArcGIS Model Builder was used for the overlay analysis to solve such multi-criteria problems of suitability. The suitability criteria 
layers were assigned weights to account for their relative importance, and overlaid using the weighted overlay tool to produce the overall land suitability map. The purpose of weighting was to express the relative importance of each factor regarding the effects on crop yield and growth rate (Perveen et al., 2007).

The analytic hierarchy process (AHP) was used to calculate the weights for the different criteria (Saaty, 1987; Chivasa et al., 2019). AHP relies on pairwise comparisons that assign values based on relative importance of criteria layers. The criteria were evaluated, and numerical scales of measurement were derived through comparing against the goal of importance for suitability. The pairwise comparison scales were assigned through discussion among experts. The overall suitability was computed by multiplying the selected criteria weight (Wi) by the assigned sub-criteria score (Xi), and summing these values in the ArcGIS Model Builder (Equation 1):

$\mathrm{S}=\sum_{i=1}^{n} W i X i$ Equation 1

Where:

$\mathrm{S}$ denotes the final land suitability score, $\mathrm{Wi}$ is the weight of the corresponding suitability criteria, $\mathrm{Xi}$ is the assigned sub-criteria score of I suitability criteria; and $n$ is the total number of criteria maps.

The final suitability result (maps and tabular data), including the explanatory document, were prepared both in softcopy and hardcopy.

Crop varieties. Faba bean varieties were chosen based on information from nationally released varieties registered by Ministry of Agriculture, Ethiopia like, productivity, earliness, grain protein content, export and local market quality parameters; and waterlogging and black root rot tolerance for Vertisols. While the list of faba bean varieties included in the suitability analysis obtained from crop variety register book (MoARD, 2006; MoARD, 2008; MoARD, 2009; MoA, 2010) and were presented (Table 2).

\section{RESULTS AND DISCUSSION}

The multi-criteria evaluation (MCE) approach in spatial analytic hierarchy process resulted in production suitable area for growing specific faba bean varieties (Table 2). The zonal statistics of each suitability map were calculated to generate percentages and area coverage of each class, by zonal and regional administrative boundaries. The results of the land suitability analysis are presented in the subsequent sections showing the extent and patterns of land area available for specific faba bean varieties for comparison with area of crop-level (faba bean) land suitability classes (Table 3).

\section{Variety level land suitability}

The following section presents varieties and their respective suitability classes in Ethiopia.

Variety Dosha (Coll 155/00-3). The suitability analysis and mapping results for this variety are shown in Figure 2 and Table 4. When compared with the overall (crop level) suitability map of faba bean by Nigussie (2014) and Table 3, the high and moderate suitable areas of Dosha variety was 5,045,228 ha that mostly covering western parts of Amhara and Oromia regional states (Table 11).

Dosha is a variety developed and released by Holleta Agricultural Research Center (HARC) in 2009. This variety yields, on average, 2.8 to6. 2 and 2.3 to $3.9 \mathrm{t} \mathrm{ha}^{-1}$ in research and farmers' fields, respectively (MoARD , 2009). It has a thousand seed weight (TSW) of 797, which is classified as V. faba var. equina with medium seeds (Cubero ,1974; Crépon et al., 2010; Pietrzak et al., 2016), and other important agronomic traits are presented in Table 2 . The variety is moderately resistant to chocolate spot and rust. 
TABLE 2. Selected characteristics of faba bean varieties used for land suitability mapping

\begin{tabular}{|c|c|c|c|c|c|c|c|c|}
\hline Variety & $\begin{array}{l}\text { Year of } \\
\text { release }\end{array}$ & $\begin{array}{l}\text { Days to } \\
\text { flowering } \\
\text { after } \\
\text { emergence }\end{array}$ & $\begin{array}{l}\text { Days to } \\
\text { maturity } \\
\text { after } \\
\text { planting } \\
\left(\mathrm{t} \mathrm{ha}^{-1}\right)\end{array}$ & $\begin{array}{l}\text { Grain yield } \\
\text { with } \\
\text { recommended } \\
\text { management }\end{array}$ & $\begin{array}{l}\text { Crude protein } \\
\text { content }(\%)\end{array}$ & $\begin{array}{c}\text { Thousand } \\
\text { grain weight } \\
\text { (g) }\end{array}$ & $\begin{array}{l}\text { Plant height } \\
\text { at heading }(\mathrm{cm})\end{array}$ & $\begin{array}{l}\text { Recommended } \\
\text { altitude (m) }\end{array}$ \\
\hline Dagm & 2002 & 67 & 152 & $3.4-3.6$ & NA & 300 & 86 & $2,600-3,000$ \\
\hline Dosha & 2009 & 60 & 144 & $2.8-6.2$ & 26.5 & 797 & 122 & $1,800-3,000$ \\
\hline Gabelcho & 2006 & 46 & 160 & $2.5-6.1$ & 26.5 & 797 & 131 & $1,900-3,000$ \\
\hline Gora & 2014 & 47 & 147 & $2.2-5.7$ & 24 & 938 & 131 & $1,900-2,800$ \\
\hline Hachalu & 2010 & 50 & 141 & $3.2-4.5$ & 27 & 890 & 128 & $1,900-2,800$ \\
\hline Moti & 2006 & 40 & 137 & $2.8-5.1$ & 27 & 781 & 124 & $1,800-3,000$ \\
\hline Walki & 2008 & 56 & 140 & $2.4-5.2$ & 27.5 & 676 & 129 & $1,900-2,800$ \\
\hline
\end{tabular}

TABLE 3. Area of land under different suitability classes for faba bean in regional states, Ethiopia

\begin{tabular}{|c|c|c|c|c|c|c|c|c|}
\hline \multirow[t]{2}{*}{ Regional states } & \multicolumn{2}{|c|}{ Highly suitable } & \multicolumn{2}{|c|}{ Moderately suitable } & \multicolumn{2}{|c|}{ Marginally suitable } & \multicolumn{2}{|c|}{ Not suitable } \\
\hline & area (ha) & $\%$ & area (ha) & $\%$ & area (ha) & $\%$ & area (ha) & $\%$ \\
\hline Amhara & 635,268 & 4.14 & $8,085,316$ & 52.8 & 450,684 & 2.94 & $6,157,636$ & 40.17 \\
\hline Oromia & $1,080,008$ & 3.62 & $10,241,276$ & 34.3 & 844,448 & 2.83 & $17,675,972$ & 59.23 \\
\hline SNNP & 165,244 & 1.56 & $3,609,584$ & 34.1 & 78,536 & 0.74 & $6,738,564$ & 63.62 \\
\hline Tigray & 1,908 & 0.04 & $1,552,112$ & 31.5 & 522,676 & 10.6 & $2,855,468$ & 57.89 \\
\hline Afar & 0 & 0 & 17,780 & 0.21 & 82,980 & 0.99 & $8,238,976$ & 98.79 \\
\hline BSG & 0 & 0 & 98,088 & 1.96 & 59,432 & 1.19 & $4,855,040$ & 96.86 \\
\hline Gambella & 0 & 0 & 52,260 & 1.76 & 4,420 & 0.15 & $2,918,540$ & 98.09 \\
\hline Somali & 0 & 0 & 89,832 & 0.26 & 202,460 & 0.58 & $34,410,444$ & 99.16 \\
\hline Total & $1,882,428$ & 1.67 & $23,746,248$ & 21.01 & $2,245,636$ & 1.99 & $83,850,640$ & 74.19 \\
\hline
\end{tabular}




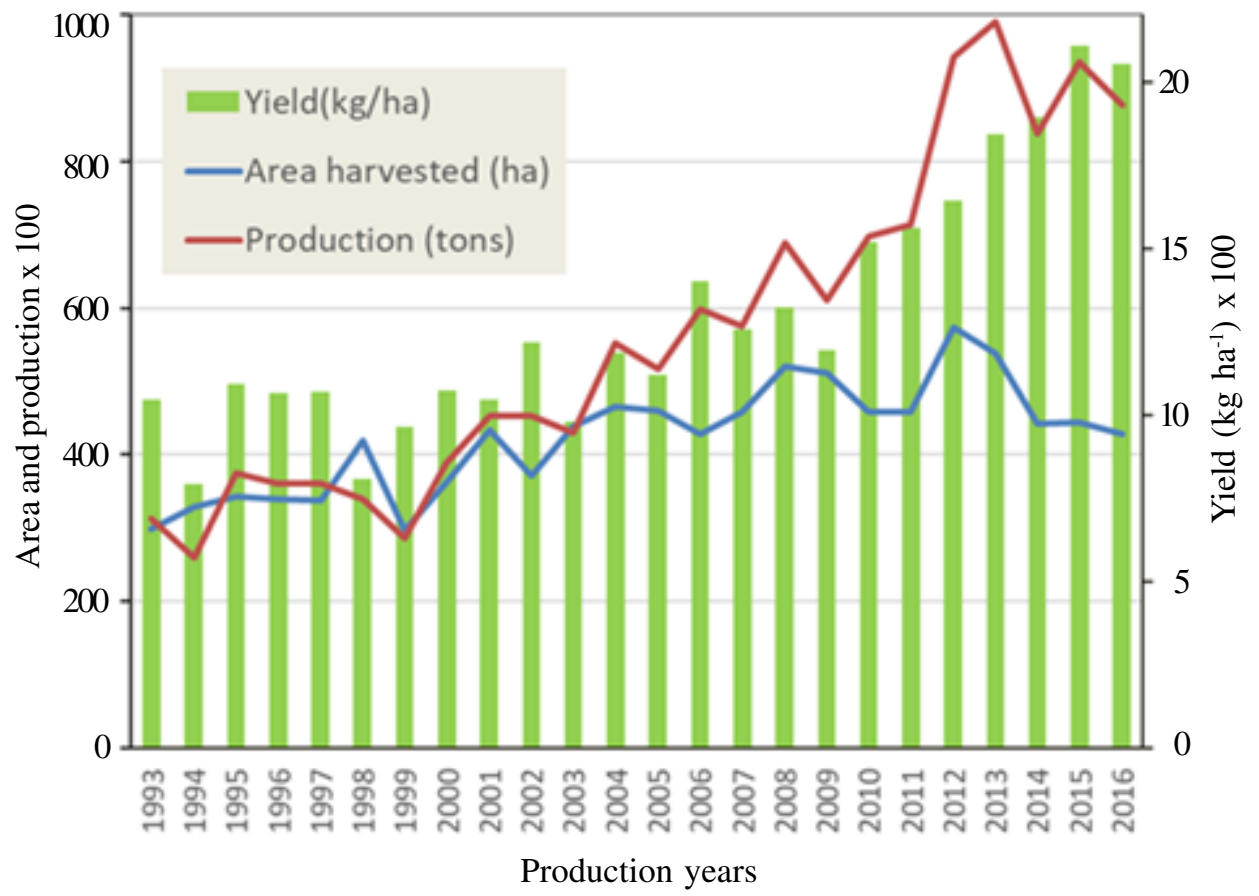

Figure 1. Faba bean harvested area, production and productivity in Ethiopia.

Data source: FAO (2019).

Variety Gabelcho (EH96009-1). The suitability analysis and mapping results for this variety are shown in Figure 3.and Table 5. When compared with the overall crop level suitability map of faba bean by Nigussie (2014), and Table 3 the high and moderate suitable areas of Gabelcho variety was 9,602,444 ha that cover Amhara and central Oromia, which are large parts of the central highlands, and extending to the Harerghie highlands in eastern parts of the country (Table 11).

Gabelcho is a variety developed and released by HARC in 2006. This variety yields, on average 2.5-6.1 and 2.0-3.0 $\mathrm{t} \mathrm{ha}^{-1}$ in research and farmers' fields, respectively (MoARD, 2006), with a TSW of $797 \mathrm{~g}$, being medium seed size. When surplus production is available, it can be used for export as it has specific market niches. Like most other varieties considered in the analysis, Gabelcho is also moderately resistant to chocolate spot and rust, it is released for soils with good drainage.
Variety Gora (EK 01024-1-2). The suitability analysis and mapping results for this variety are shown in Figure 4 and Table 6. When compared with the overall crop level suitability map of faba bean Nigussie (2014), and Table 3 the high and moderate suitable areas of Gora variety was $7,275,888$ ha that cover western parts of Amhara and Oromia, and northern parts of Southern Nations Nationalities and People (SNNP) regional states (Table 11).

Gora is a variety developed and released by Kulumsa Agricultural Research Center (KARC) in 2013. This variety yields, on average, 2.2 to 5.7 and 2.0 to $4.0 \mathrm{t} \mathrm{ha}^{-1}$ in research and farmers' fields, respectively, with a high TSW of $938 \mathrm{~g}$ (Table 2; MoA 2014). The variety is moderately resistant to chocolate spot and rust.

Variety Moti (EH95078-6). The variety level suitability analysis and mapping results for this variety are shown in Figure 5 and Table 7. 
TABLE 4. Area of land under different suitability classes for var. Dosha in regional states

\begin{tabular}{|c|c|c|c|c|c|c|c|c|}
\hline \multirow[t]{2}{*}{ Regional states } & \multicolumn{2}{|c|}{ Highly suitable } & \multicolumn{2}{|c|}{ Moderately suitable } & \multicolumn{2}{|c|}{ Marginally suitable } & \multicolumn{2}{|c|}{ Not suitable } \\
\hline & area (ha) & $\%$ & area (ha) & $\%$ & area (ha) & $\%$ & area (ha) & $\%$ \\
\hline Amhara & 8,220 & 0.05 & $1,918,680$ & 12.33 & 49,884 & 0.32 & $13,586,585$ & 87.3 \\
\hline Oromia & 15,348 & 0.05 & $2,691,584$ & 8.29 & 50,908 & 0.16 & $29,691,573$ & 91.5 \\
\hline SNNP & 0 & 0 & 343,836 & 3.05 & 34,720 & 0.31 & $10,911,430$ & 96.65 \\
\hline Tigray & 100 & 0 & 40,460 & 0.81 & 0 & 0 & $4,980,098$ & 99.19 \\
\hline Afar & 0 & 0 & 0 & 0 & 0 & 0 & $9,562,336$ & 100 \\
\hline BSG & 4 & 0 & 26,996 & 0.54 & 0 & 0 & $4,973,357$ & 99.46 \\
\hline Gambella & 0 & 0 & 0 & 0 & 0 & 0 & $2,570,136$ & 100 \\
\hline Somali & 0 & 0 & 0 & 0 & 0 & 0 & $31,561,965$ & 100 \\
\hline Total & 23,672 & 0.02 & $5,021,556$ & 4.44 & 135,512 & 0.12 & $107,837,480$ & 95.42 \\
\hline
\end{tabular}

TABLE 5. Area of land under different suitability classes for var. Gabelcho by regional states

\begin{tabular}{|c|c|c|c|c|c|c|c|c|}
\hline \multirow[t]{2}{*}{ Regional states } & \multicolumn{2}{|c|}{ Highly suitable } & \multicolumn{2}{|c|}{ Moderately suitable } & \multicolumn{2}{|c|}{ Marginally suitable } & \multicolumn{2}{|c|}{ Not suitable } \\
\hline & area (ha) & $\%$ & area (ha) & $\%$ & area (ha) & $\%$ & area (ha) & $\%$ \\
\hline Amhara & 57,700 & 0.37 & $4,903,888$ & 31.51 & 245,648 & 1.58 & $10,356,133$ & 66.54 \\
\hline Oromia & 131,300 & 0.4 & $3,895,960$ & 12.01 & 52,472 & 0.16 & $28,369,681$ & 87.43 \\
\hline SNNP & 388 & 0 & 393,576 & 3.49 & 5,480 & 0.05 & $10,890,542$ & 96.46 \\
\hline Tigray & 3,448 & 0.07 & 213,644 & 4.26 & 1,452 & 0.03 & $4,802,114$ & 95.65 \\
\hline Afar & 0 & 0 & 0 & 0 & 0 & 0 & $9,562,336$ & 100 \\
\hline BSG & 0 & 0 & 2,372 & 0.05 & 220 & 0 & $4,997,765$ & 99.95 \\
\hline Gambella & 0 & 0 & 0 & 0 & 0 & 0 & $2,570,136$ & 100 \\
\hline Somali & 0 & 0 & 168 & 0 & 96 & 0 & $31,561,701$ & 100 \\
\hline Total & 192,836 & 0.17 & $9,409,608$ & 8.33 & 305,368 & 0.27 & $103,110,408$ & 91.23 \\
\hline
\end{tabular}




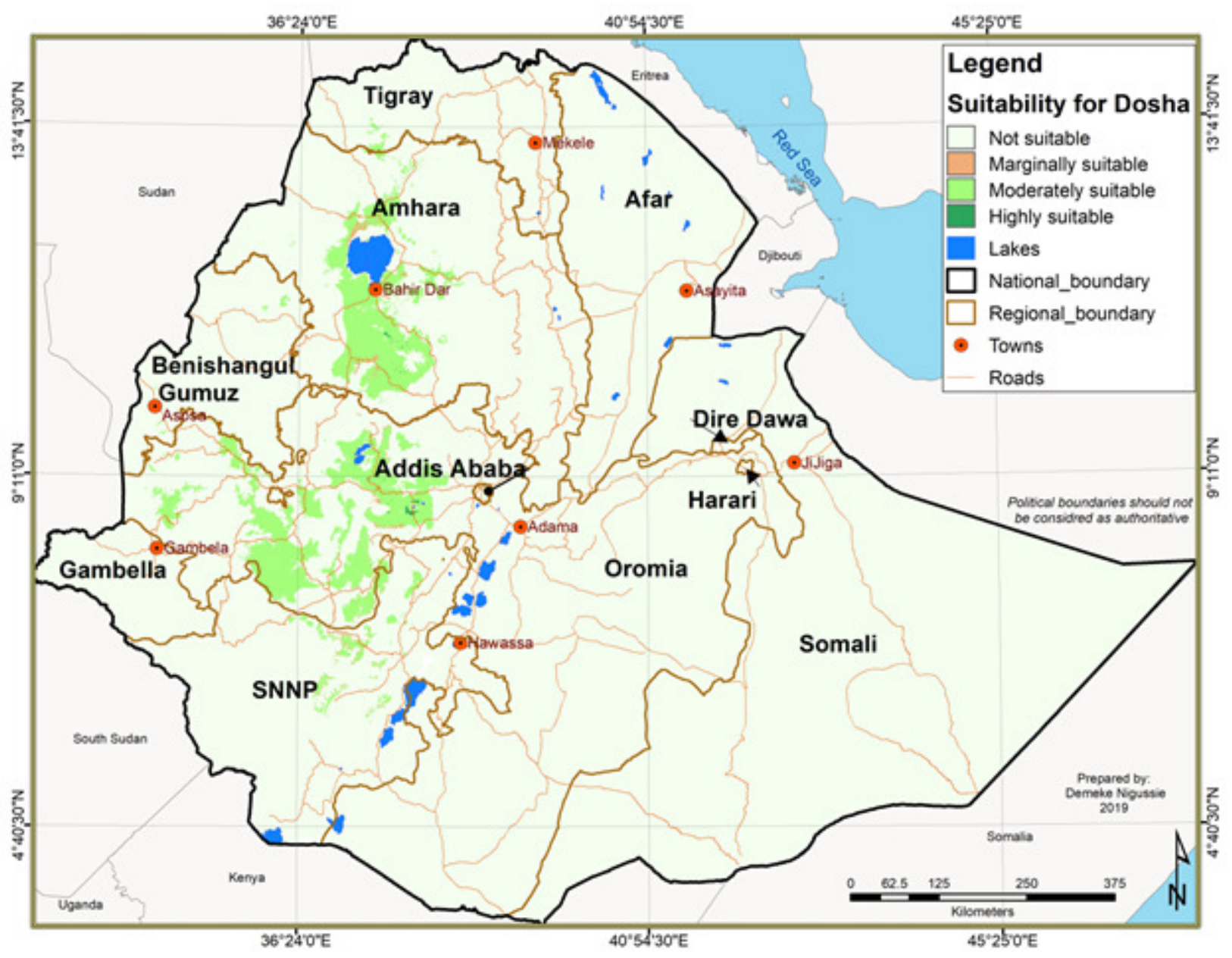

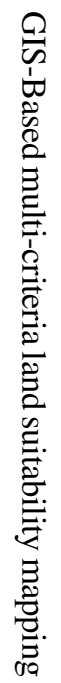

Figure 2. Land suitability map for faba bean var. Doshaas established in the present study. 


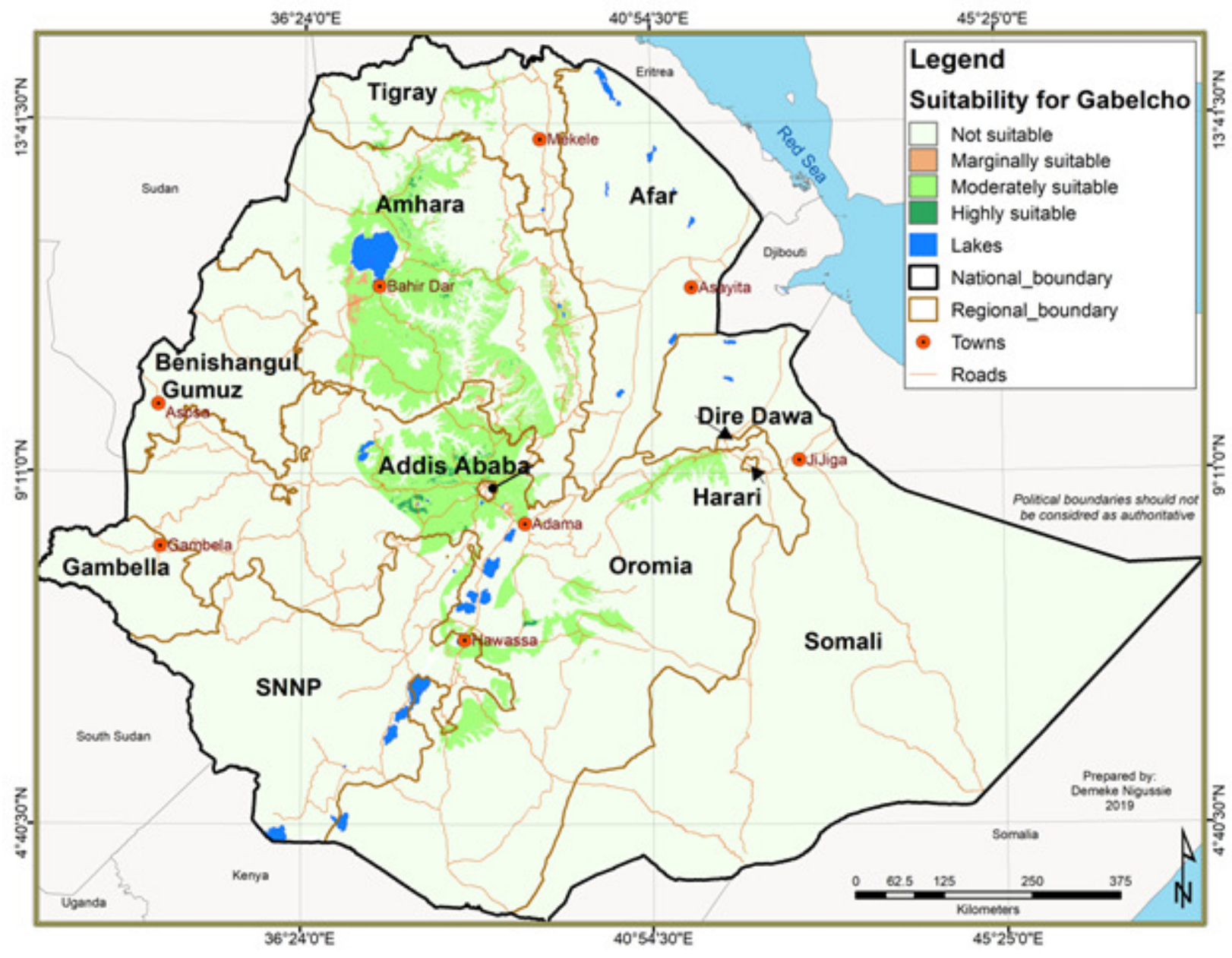

Figure 3. Land suitability map for faba bean var. Gabelchoas established in the present study. 


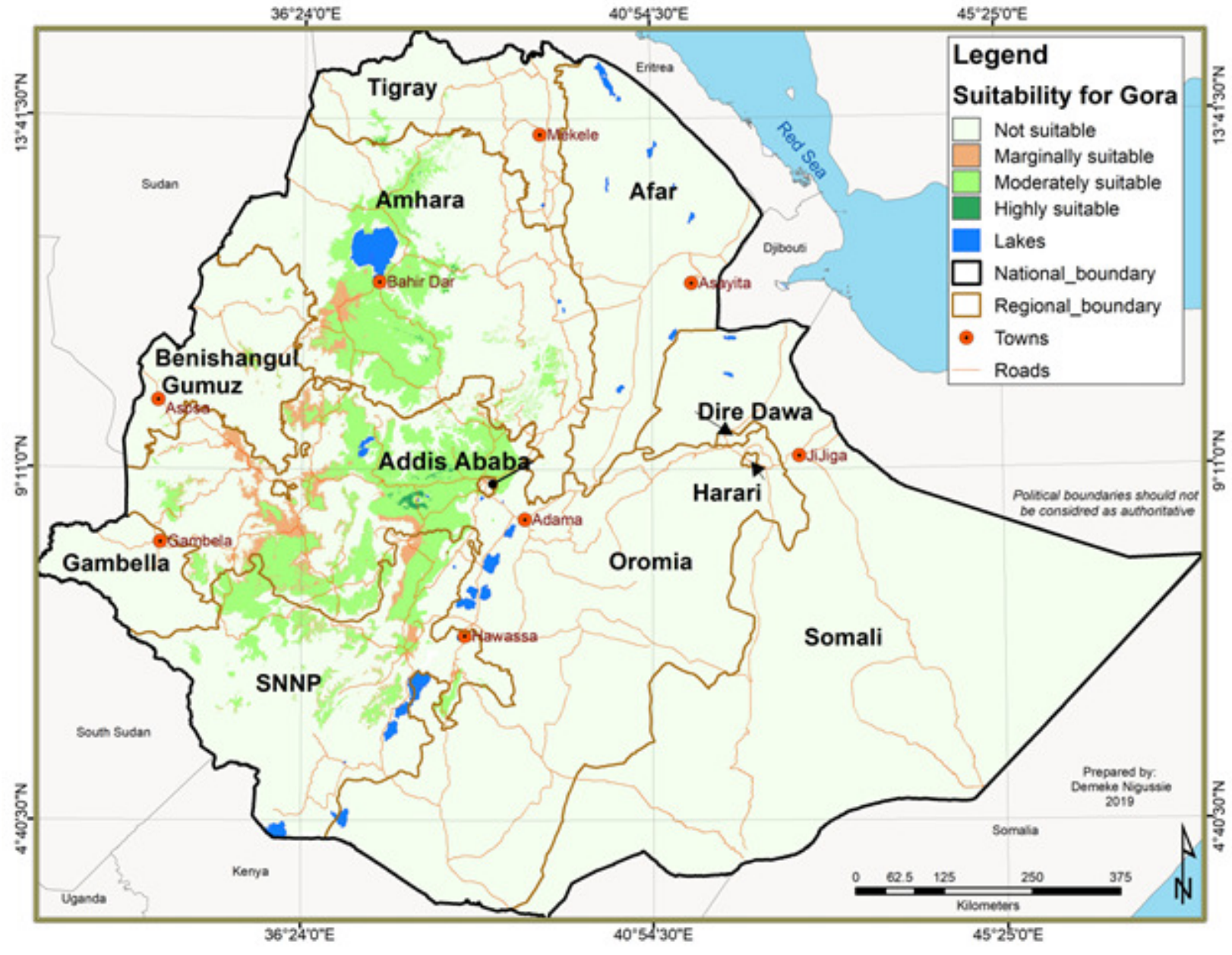

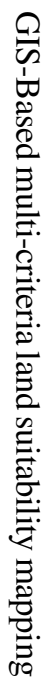

Figure 4. Land suitability map for faba bean var. Gora as established in the present study. 
When compared with the overall crop level suitability map of faba bean, the high and moderate suitable areas of Moti variety was $15,615,960$ ha. It has better area coverage in large parts of the central highlands and extends to the Harerghie highlands in the east and south-west of the country (Table 11).

Moti is a variety developed and released by HARC in 2006. This variety yields, on average, 2.8 to 5.1 and 2.3 to $3.5 \mathrm{t} \mathrm{ha}^{-1}$ in research and farmers' fields, respectively, with a TSW of $781 \mathrm{~g}$ (MoARD, 2006). The variety is moderately resistant to chocolate spot and rust and matures early (Table 2), which means it is suitable to areas with a relatively short cropping season that have moderate rainfall.

Variety Dagm (Grarjarso 89-8). The variety level suitability analysis and mapping results for this variety are shown in Figure 6 and Table 8 .When compared with the overall crop level suitability map of faba bean shown by Nigussie (2014) and Table 3. The high and moderate suitable areas of Dagm variety was $4,663,812 \mathrm{ha}$. Where mostly covering western parts of Amhara and Oromia regions and small patches in SNNP region, where waterlogging of heavy black soils was limits faba bean production (Table 11).

Dagm is a variety developed and released by Sheno Agricultural Research Center (now Debre Berhan Agricultural Research Center (DBARC) in 2002. This variety was released for Vertisols and is believed to perform better than other varieties on Vertisols, is limited to heavy black soil of Vertisols and its promotion is low at national level. This variety yields, on average, 2.8 to $6.2 \mathrm{t} \mathrm{ha}^{-1}$ in research fields (NAIA, 2003). It is small seeded with TSW of $300 \mathrm{~g}$ TSW (Table 2). The variety is highly tolerant to black root rot and chocolate spot. Due to its small seed size, it is sold in local markets to prepare popular dishes, such as shiro wot.

Variety Hachalu (EH00102-4-1). The variety level suitability analysis and mapping results for this variety are shown in Figure 7 and 


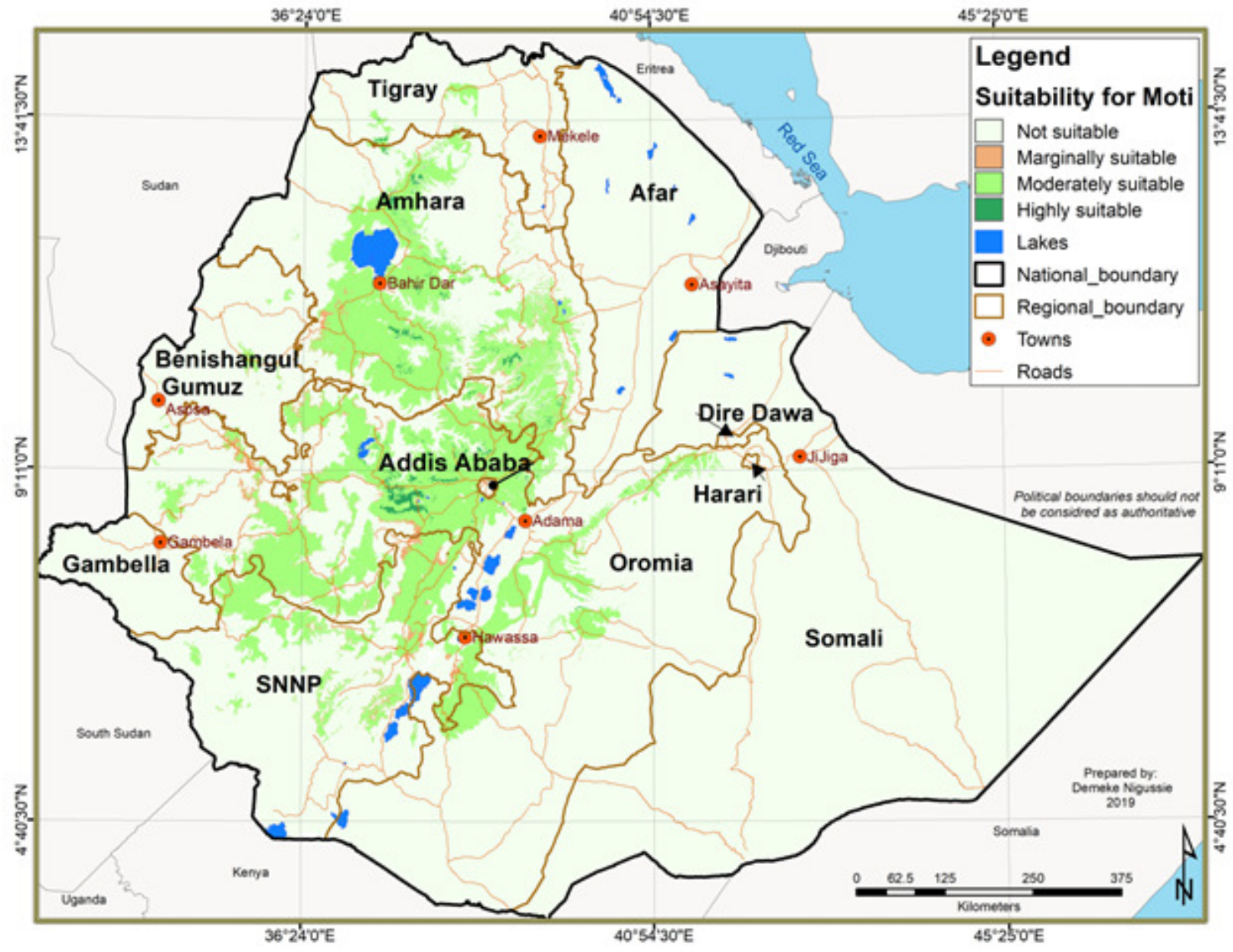

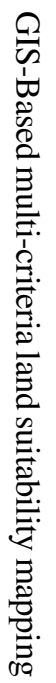

Figure 5. Land suitability map for faba bean var.Motias established in the present study. 
TABLE 7. Area of land under different suitability for var. Moti in regional states

\begin{tabular}{|c|c|c|c|c|c|c|c|c|}
\hline \multirow[t]{2}{*}{ Regional states } & \multicolumn{2}{|c|}{ Highly suitable } & \multicolumn{2}{|c|}{ Moderately suitable } & \multicolumn{2}{|c|}{ Marginally suitable } & \multicolumn{2}{|c|}{ Not suitable } \\
\hline & area (ha) & $\%$ & area (ha) & $\%$ & area (ha) & $\%$ & area (ha) & $\%$ \\
\hline Amhara & 132,888 & 0.85 & $5,495,292$ & 35.31 & 163,120 & 1.05 & $9,772,069$ & 62.79 \\
\hline Oromia & 184,884 & 0.57 & $6,933,696$ & 21.37 & 292,568 & 0.9 & $25,038,265$ & 77.16 \\
\hline SNNP & 0 & 0 & $2,613,396$ & 23.15 & 208,688 & 1.85 & $8,467,902$ & 75 \\
\hline Tigray & 7,888 & 0.16 & 150,424 & 3 & 412 & 0.01 & $4,861,934$ & 96.84 \\
\hline Afar & 0 & 0 & 36 & 0 & 0 & 0 & $9,562,300$ & 100 \\
\hline BSG & 0 & 0 & 91,212 & 1.82 & 9,796 & 0.2 & $4,899,349$ & 97.98 \\
\hline Gambella & 0 & 0 & 6,244 & 0.24 & 4 & 0 & $2,563,888$ & 99.76 \\
\hline Somali & 0 & 0 & 0 & 0 & 0 & 0 & $31,561,965$ & 100 \\
\hline Total & 325,660 & 0.29 & $15,290,300$ & 13.53 & 674,588 & 0.60 & $96,727,672$ & 85.59 \\
\hline \multirow[t]{2}{*}{ Regional states } & \multicolumn{2}{|c|}{ Highly suitable } & \multicolumn{2}{|c|}{ Moderately suitable } & \multicolumn{2}{|c|}{ Marginally suitable } & \multicolumn{2}{|c|}{ Not suitable } \\
\hline & area (ha) & $\%$ & area (ha) & $\%$ & area (ha) & $\%$ & area (ha) & $\%$ \\
\hline Amhara & 30,876 & 0.2 & $2,380,028$ & 15.29 & 43,688 & 0.28 & $13,108,777$ & 84.23 \\
\hline Oromia & 22,776 & 0.07 & $1,827,616$ & 5.63 & 47,568 & 0.15 & $30,551,453$ & 94.15 \\
\hline SNNP & 48 & 0 & 307,896 & 2.73 & 41,412 & 0.37 & $10,940,630$ & 96.91 \\
\hline Tigray & 268 & 0.01 & 68,704 & 1.37 & 5,220 & 0.1 & $4,946,466$ & 98.52 \\
\hline Afar & 0 & 0 & 0 & 0 & 0 & 0 & $9,562,336$ & 100 \\
\hline BSG & 0 & 0 & 25,592 & 0.51 & 2,848 & 0.06 & $4,971,917$ & 99.43 \\
\hline Gambella & 0 & 0 & 8 & 0 & 0 & 0 & $2,570,128$ & 100 \\
\hline Somali & 0 & 0 & 0 & 0 & 0 & 0 & $31,561,965$ & 100 \\
\hline Total & 53,968 & 0.05 & $4,609,844$ & 4.08 & 140,736 & 0.12 & $108,213,672$ & 95.75 \\
\hline
\end{tabular}




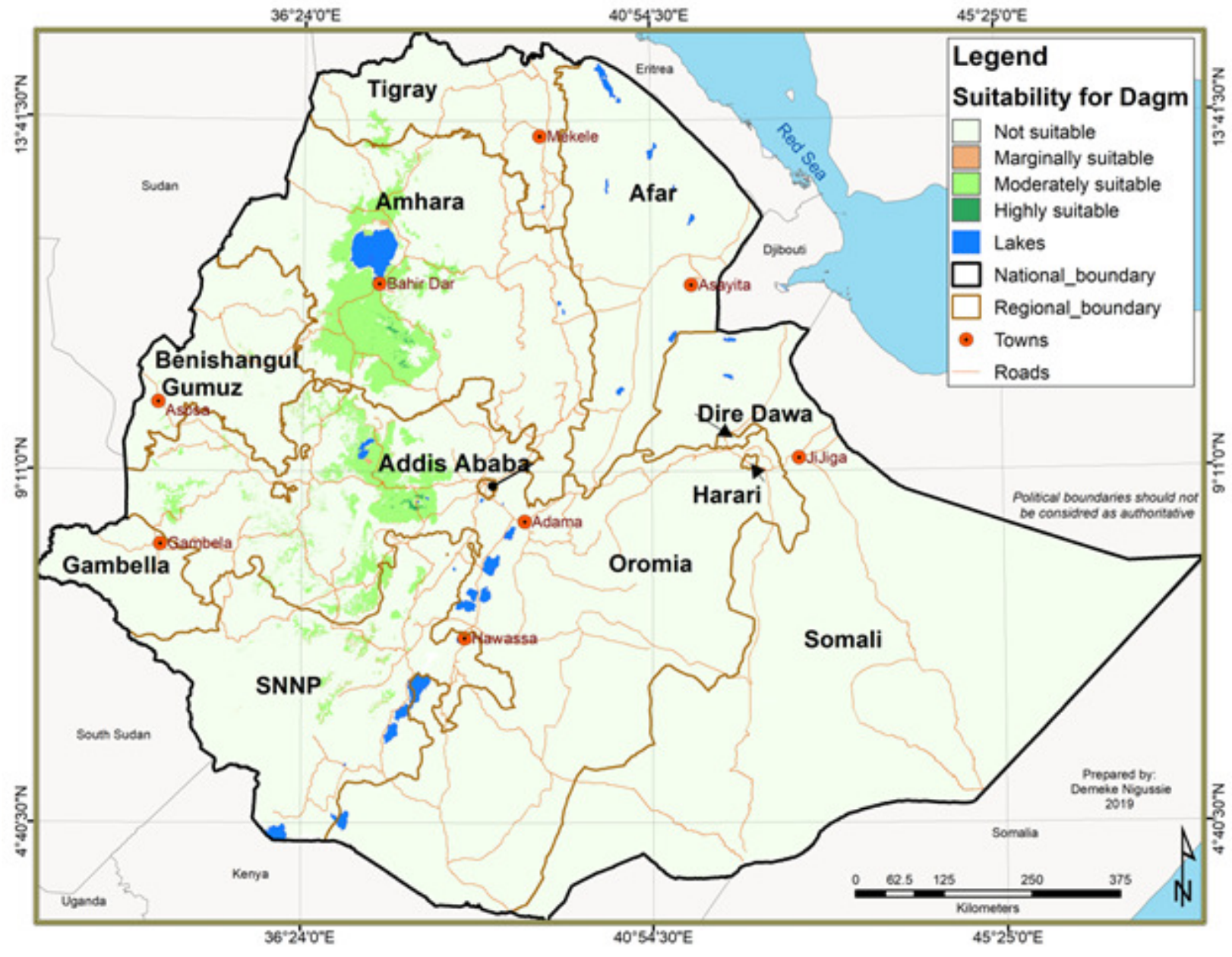

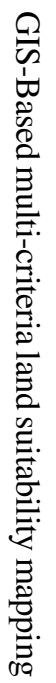

Figure 6. Land suitability map for faba bean var. Dagmas established in the present study. 
TABLE 9. Area of land under different suitability for var. Hachalu in regional states

\begin{tabular}{|c|c|c|c|c|c|c|c|c|}
\hline \multirow[t]{2}{*}{ Regional states } & \multicolumn{2}{|c|}{ Highly suitable } & \multicolumn{2}{|c|}{ Moderately suitable } & \multicolumn{2}{|c|}{ Marginally suitable } & \multicolumn{2}{|c|}{ Not suitable } \\
\hline & area (ha) & $\%$ & area (ha) & $\%$ & area (ha) & $\%$ & area (ha) & $\%$ \\
\hline Amhara & 37,860 & 0.24 & $3,754,940$ & 24.13 & 28,756 & 0.18 & $11,741,813$ & 75.45 \\
\hline Oromia & 96,812 & 0.3 & $3,619,408$ & 11.15 & 92,144 & 0.28 & $28,641,049$ & 88.26 \\
\hline SNNP & 52 & 0 & $1,352,132$ & 11.98 & 75,620 & 0.67 & $9,862,182$ & 87.35 \\
\hline Tigray & 1,476 & 0.03 & 65,208 & 1.3 & 84 & 0 & $4,953,890$ & 98.67 \\
\hline Afar & 0 & 0 & 0 & 0 & 0 & 0 & $9,562,336$ & 100 \\
\hline BSG & 0 & 0 & 41,608 & 0.83 & 1,132 & 0.02 & $4,957,617$ & 99.15 \\
\hline Gambella & 0 & 0 & 96 & 0 & 0 & 0 & $2,570,040$ & 100 \\
\hline Somali & 0 & 0 & 0 & 0 & 0 & 0 & $31,561,965$ & 100 \\
\hline Total & 136,200 & 0.12 & $8,833,392$ & 7.82 & 197,736 & 0.17 & $103,850,892$ & 91.89 \\
\hline
\end{tabular}

Table 10. Area of land under different suitability for var. Walki in regional states

\begin{tabular}{|c|c|c|c|c|c|c|c|c|}
\hline \multirow[t]{2}{*}{ Regional states } & \multicolumn{2}{|c|}{ Highly suitable } & \multicolumn{2}{|c|}{ Moderately suitable } & \multicolumn{2}{|c|}{ Marginally suitable } & \multicolumn{2}{|c|}{ Not suitable } \\
\hline & area (ha) & $\%$ & area (ha) & $\%$ & area (ha) & $\%$ & area (ha) & $\%$ \\
\hline Amhara & 78,228 & 0.5 & $3,358,480$ & 21.58 & 136,368 & 0.88 & $11,990,293$ & 77.04 \\
\hline Oromia & 178,140 & 0.55 & $2,842,356$ & 8.76 & 172,940 & 0.53 & $29,255,977$ & 90.16 \\
\hline SNNP & 0 & 0 & 1200676 & 10.63 & 94,872 & 0.84 & $9,994,438$ & 88.52 \\
\hline Tigray & 8,516 & 0.17 & 54,760 & 1.09 & 0 & 0 & $4,957,382$ & 98.74 \\
\hline Afar & 0 & 0 & 0 & 0 & 0 & 0 & $9,562,336$ & 100 \\
\hline BSG & 0 & 0 & 17,296 & 0.35 & 5,076 & 0.1 & $4,977,985$ & 99.55 \\
\hline Gambella & 0 & 0 & 8 & 0 & 0 & 0 & $2,570,128$ & 100 \\
\hline Somali & 0 & 0 & 0 & 0 & 0 & 0 & $31,561,965$ & 100 \\
\hline Total & 264,884 & 0.23 & $7,473,576$ & 6.61 & 409,256 & 0.36 & $104,870,504$ & 92.79 \\
\hline
\end{tabular}




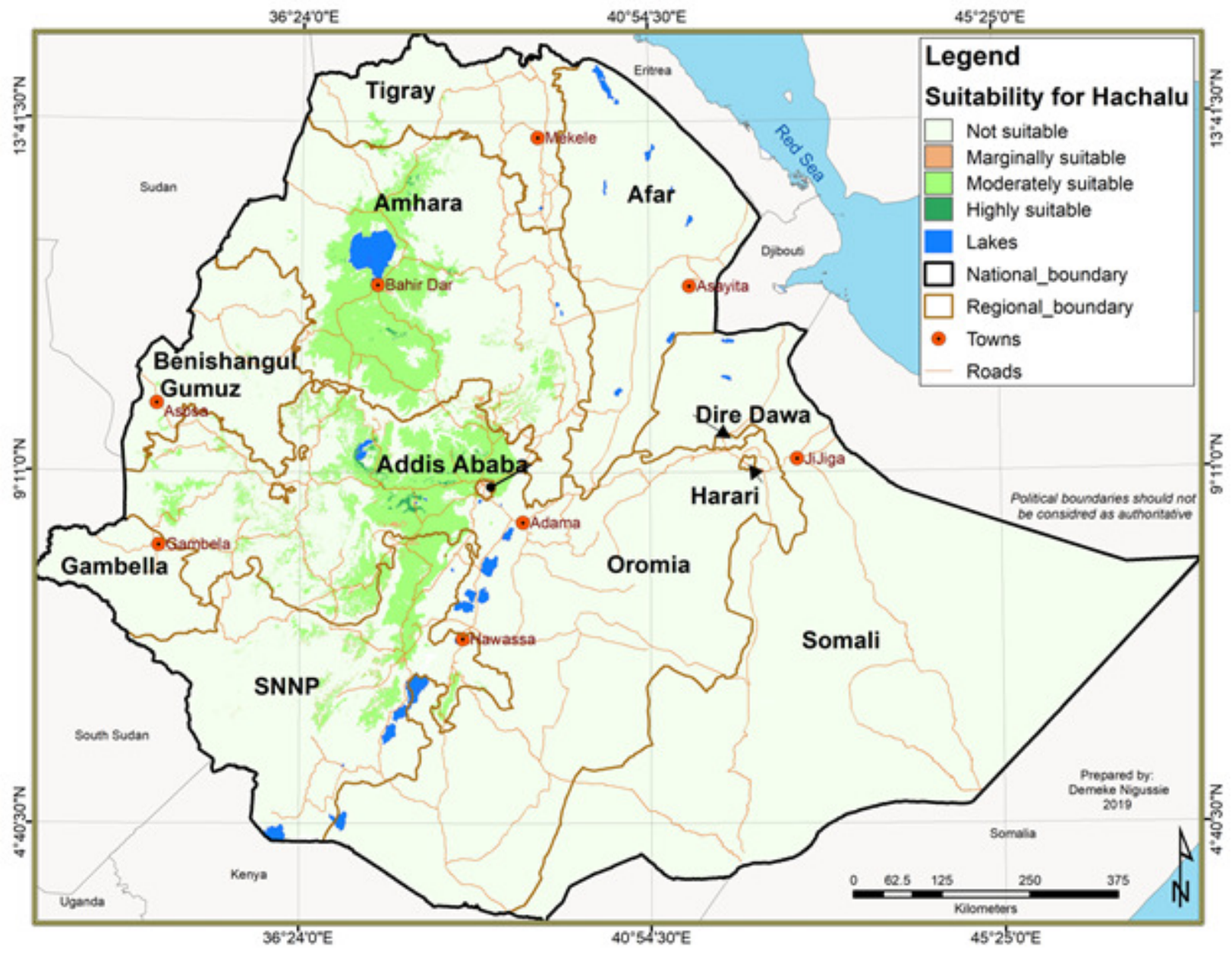

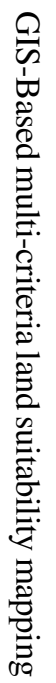

Figure 7. Land suitability map for faba bean var. Hachaluas established in the present study. 


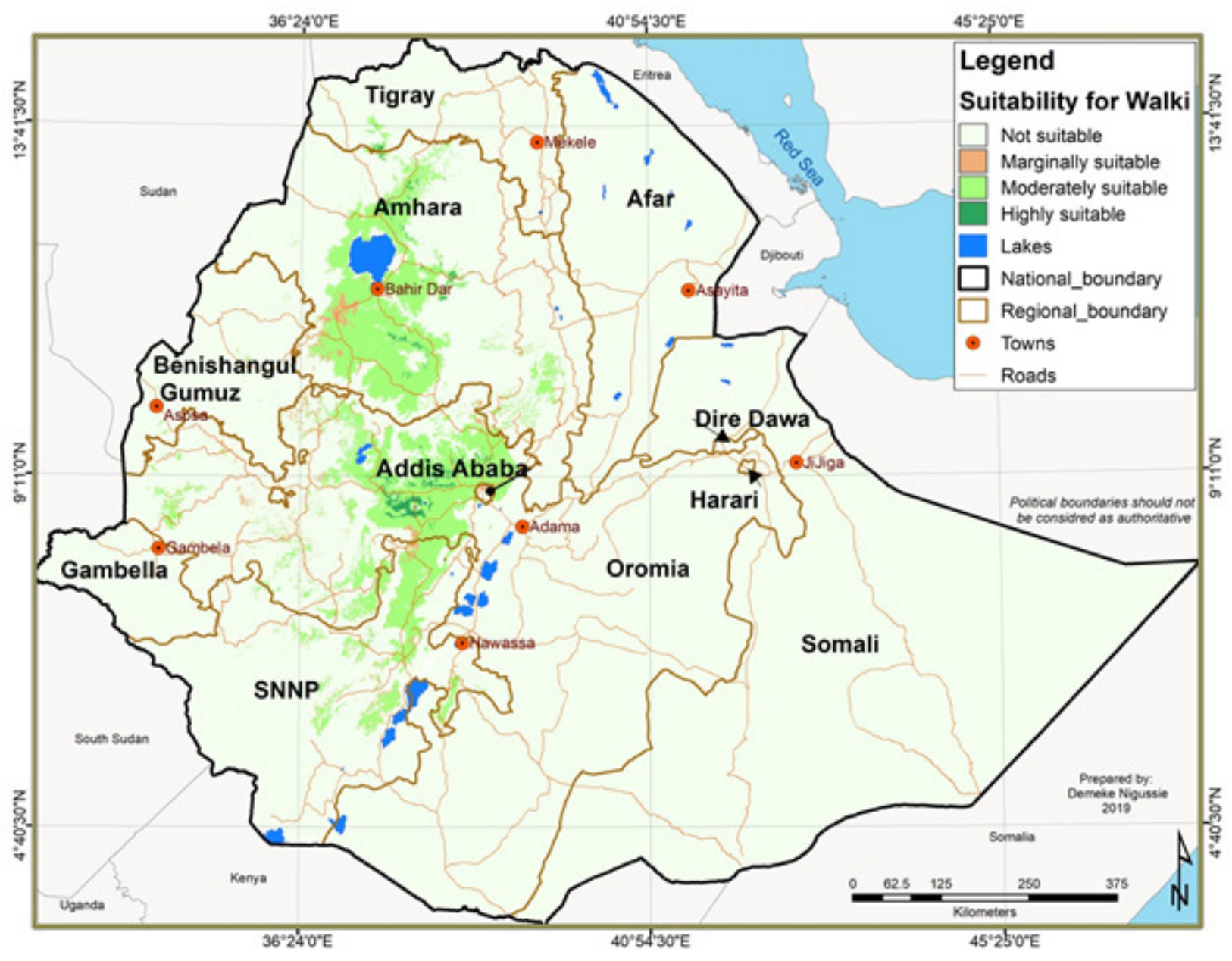

Figure 8. Land suitability map for faba bean var. Walkias established in the present study. 
TABLE 11. Land suitability for faba bean varieties in Ethiopia

\begin{tabular}{|c|c|c|c|}
\hline Variety & $\begin{array}{l}\text { Suitability } \\
\text { classes }\end{array}$ & Area(ha) & Major zones \\
\hline \multirow[t]{2}{*}{ Dosha } & $\mathrm{S}_{1}$ & 23,672 & $\begin{array}{l}\text { South West Shewa, West Shewa, West Gojam, East Gojam, South Gonder, Horo Guduru, North Gonder, Western, East } \\
\text { Wellega, Metekel, Jimma, Ilubabor, West Wellega, Kelem Wellega, Dawro }\end{array}$ \\
\hline & $\mathrm{S}_{2}$ & $5,021,556$ & $\begin{array}{l}\text { West Gojam, Jimma, West Shewa, East Gojam, Ilubabor, North Gonder, Horo Guduru, East Wellega, South Gonder, West } \\
\text { Wellega, Kelem Wellega, South West Shewa, Dawro, Gamo Gofa, Awi/Agew }\end{array}$ \\
\hline \multirow[t]{2}{*}{ Gabelcho } & S1 & 192,836 & $\begin{array}{l}\text { West Shewa, North Gonder, North Shewa (Oromia), South West Shewa, South Gonder, Arsi, South Wollo, West Arsi, } \\
\text { Western, East Gojam, North Shewa (Amhara), Addis Ababa, West Gojam, Bale, Gurage }\end{array}$ \\
\hline & $\mathrm{S}_{2}$ & $9,409,608$ & $\begin{array}{l}\text { East Gojam, North Gonder, West Shewa, West Gojam, South Gonder, North Shewa ( Oromia), South Wollo, North } \\
\text { Shewa (Amhara), South West Shewa, Guji, Bale, West Arsi, Arsi, East Shewa, North Wollo }\end{array}$ \\
\hline \multirow[t]{2}{*}{ Gora } & $\mathrm{S}_{1}$ & 107,740 & $\begin{array}{l}\text { South West Shewa, North Gonder, South Gonder, East Gojam, Western, North Shewa (Oromia), West Gojam, Horo } \\
\text { Guduru, South Wollo, North Shewa (Amhara) Region, Jimma, Gurage, Awi, Gamo Gofa }\end{array}$ \\
\hline & $\mathrm{S}_{2}$ & $7,168,148$ & $\begin{array}{l}\text { West Shewa, West Gojam, North Gonder, East Gojam, North Shewa( Oromia), South Gonder, South West Shewa, Jimma, } \\
\text { Horo Guduru, Gurage, Awi, North Shewa (Amhara), Gamo Gofa, Hadiya, East Wellega }\end{array}$ \\
\hline \multirow[t]{2}{*}{ Moti } & $\mathrm{S}_{1}$ & 325,660 & $\begin{array}{l}\text { West Shewa, North Gonder, South West Shewa, South Wollo, East Gojam, South Gonder, North Shewa (Oromia), North } \\
\text { Shewa (Amhara), West Gojam, Horo Guduru, Western, Arsi, East Shewa, Bale, West Harerge }\end{array}$ \\
\hline & $\mathrm{S}_{2}$ & $15,290,300$ & $\begin{array}{l}\text { Jimma, West Gojam, West Shewa, East Gojam, North Gonder, South Wollo, North Shewa ( Oromia), North Shewa } \\
\text { (Amhara), Arsi, South Gonder, Ilubabor, Keffa, South West Shewa, East Wellega, Horo Guduru }\end{array}$ \\
\hline \multirow[t]{2}{*}{ Dagm } & $\mathrm{S}_{1}$ & 53,968 & $\begin{array}{l}\text { West Gojam, West Shewa, East Gojam, South West Shewa, South Gonder, North Gonder, Horo Guduru, Western, Jimma, } \\
\text { Dawro, East Wellega, Awi, Kelem Wellega, Ilubabor, Gamo Gofa }\end{array}$ \\
\hline & $\mathrm{S}_{2}$ & $4,609,844$ & $\begin{array}{l}\text { West Gojam, West Shewa, North Gonder, East Gojam, Jimma, Awi, Horo Guduru, South Gonder, East Wellega, South } \\
\text { West Shewa, Kelem Wellega, Western, Ilubabor, Gamo Gofa, Keffa }\end{array}$ \\
\hline \multirow[t]{2}{*}{ Hachalu } & $\mathrm{S}_{1}$ & 136,200 & $\begin{array}{l}\text { West Shewa, Horo Guduru, North Gonder, South West Shewa, West Gojam, South Gonder, North Shewa (Oromia) } \\
\text { ( East Gojam, Western, East Wellega, Jimma, Dawro, North Shewa (Amhara), Awi, Gurage }\end{array}$ \\
\hline & $\mathrm{S}_{2}$ & $8,833,392$ & $\begin{array}{l}\text { West Gojam, North Gonder, East Gojam, North Shewa (Oromia), South Gonder, Jimma, South West Shewa, Awi, Gurage, } \\
\text { Horo Guduru, East Wellega, Gamo Gofa, Hadiya, North Shewa ( Amhara ) }\end{array}$ \\
\hline \multirow[t]{2}{*}{ Walki } & $\mathrm{S}_{1}$ & 264,884 & $\begin{array}{l}\text { West Shewa, North Gonder, South West Shewa, South Gonder, East Gojam, North Shewa of Oromia Region, Western, West } \\
\text { Gojam, Horo Guduru, North Shewa ( Amhara), Addis Abeba, South Wollo, Jimma, Gurage, Awi }\end{array}$ \\
\hline & $\mathrm{S}_{2}$ & $7,473,576$ & $\begin{array}{l}\text { West Gojam, West Shewa, North Gonder, East Gojam, North Shewa (Oromia) South Gonder, South West Shewa, } \\
\text { Jimma, Horo Guduru, Gurage, Awi, Hadiya, Gamo Gofa, North Shewa (Amhara), East Wellega }\end{array}$ \\
\hline
\end{tabular}


Table 9. When compared with the overall crop level suitability map of faba bean Nigussie, (2014), Table 3. The high and moderate suitable areas of Hachalu variety was 8,969,592 ha. While mostly covering the western part of Amhara and Oromia regions and the northern part of South Nation and nationality people SNNP region (Table 11).

Hachalu is a variety developed and released by HARC in 2010. This variety is also released for Vertisols and performs better in grain yield and TSW than other varieties released by NARS in previous years (Table 2). However, it is less tolerant to waterlogging than Dagm. This variety yields on average, 3.2 to 4.5 and 2.4 to $3.5 \mathrm{t} \mathrm{ha}^{-1}$ in research and farmers' fields, respectively, having a medium seed size with TSW of $890 \mathrm{~g}$ (Table 2 ; MoA, 2010). It has the largest seed size compared to other faba bean varieties released for Vertisols and those released, except Gora, for light soils. The variety is tolerant to black root rot, chocolate spot and rust MoA (2010).

Variety Walki (EH96049-2). The variety level suitability analysis and mapping results for this variety are shown in Figure 8 and Table10. When compared with the overall (crop level) suitability map of faba bean, The high and moderate suitable areas of Walki variety was 7,738,460 ha. Where covering the west-central highlands of Ethiopia including parts of Amhara, Oromia and SNNP regions (Table 11).

Walki is a variety developed and released by HARC in 2008. It was also released for Vertisols and yields on average, 2.4 to 5.2 and 2.0 to $4.2 \mathrm{tha}^{-1}$ at research and farmers' fields, respectively (MoARD, 2008). Walki performs better on light Vertisols which need welldrained, but should be supported by Broad bed furrow (BBF) on heavy Vertisols for which it is released. Besides, it has a larger seed size with TSW of $676 \mathrm{~g}$ compared with Dagm which also released for vertisol and small seed size. The variety is moderately resistant to chocolate spot and rust.

\section{CONCLUSION}

This study is a national level and broad scale suitability analysis without considering irrigation potentials and socioeconomic aspects. With all its data limitations, the following are the main summaries of the variety level suitability analysis for faba bean:

(i) Amhara, Oromia, SNNP and Tigray remain the major regions with suitable areas for production of existing varieties of faba bean compared to Afar, Benishangul Gumuz, Gambella, and Somali regions. However, the highly suitable areas are limited compared to moderately suitable areas, which are higher across the regions.

(ii) In general, areas of the highly and moderately suitable lands for faba bean varieties considered in this analysis are smaller than the areas of faba bean crop level suitability Table 3 .

(iii) For faba bean varieties considered in this analysis, the highly and moderately suitable areas of each variety was relatively small entail to push faba bean production to marginal areas solving the constraints like draught.. However, Moti followed by Gabelcho, Hacahlu and Walki have broader adaptation than the rest of varieties based on their suitability area coverage.

(IV) For most faba bean varieties analysed, Oromia had more highly suitable areas; whereas Amhara has more moderately suitable areas than other regions. Amhara region has the highest moderately suitable areas for Gabelcho, Moti and Gora accounting for $31.5,35.3$ and $21.16 \%$, respectively.

(V) The suitability analysis results show that the currently available improved varieties of faba bean can be targeted for scaling out in the identified land suitability classes in Ethiopia with agricultural researcher consultation and local expert advice. 
(VI) This study is a broad scale nationwide suitability analysis based on biophysical factors and intended to serve as a guide for agricultural research and development related policy and decision-making at national level. One of the constraints that limit the quality of these suitability analyses and mapping is the lack of fineresolution geospatial data to combine both biophysical and socioeconomic factors. The quality and scale of this work is dependent on the quality of geospatial data and information of environmental requirements of the different varieties included in this analysis. Hence, it should be noted that the outputs may not directly be used for applications that demand finer resolutions (e.g. at farm scale).

\section{ACKNOWLEDGMENT}

This study was supported by the Seeds and Technology Scaling Projects of Chickpea, Faba bean and Malt barley funded by USAID and implemented by ICARDA, in collaboration with the Federal and regional agricultural research institutes, seed producers and suppliers, development practitioners and farmer's organizations in Ethiopia. The authors are grateful for the financial support of ICARDA and USAID, and provision of data by breeders from NARS partners and Plant and Variety Release, Protection and Seed Quality Control of the Ministry of Agriculture without which this study would not have been possible.

\section{REFERENCES}

Abebe, T.T, Belay, G.W., Keneni, G.W. and Tadesse, T.M. 2017. Fungicidal management of the newly emerging faba bean disease "gall (Olpidium viciae Kusano) in Tigray. Ethiopia Crop Protection Journal 107:19-25

Cubero, J. I. 1974. On theevolution of Vicia faba L. Theoretical and Applied Genetics 45:47-51. doi: 10.1007/BF00283475
Crépon, K., Marget, P., Peyronnet, C., Marget, P., Peyronnet, C.and Carrouée, B. 2010. Nutritional value of faba bean (Vicia faba L.) seeds for feed and food. Field Crop Research 115:329-339. doi: 10.1016/ j.fcr.2009.09.01

Chivasa, W., Mutanga, O. and Biradar, C. 2019. Mapping land suitability for maize (Zea mays L.) production using GIS and AHP technique in Zimbabwe. South African Journal of Geomatics 8 (2): 249-265.

Dereje, G., Wondafrash, M. and Gemechu, K. 2012. Faba bean galls: A new disease of faba bean in Ethiopia. pp. 1 - 6. Available at: http://Google.doc.com.. Accessed on 10 June 2018.

Elsheikh, F. and Abdalla, R. 2016. Physical land suitability assessment based on FAO framework. IOSR Journal of Engineering 12 (6):36-44.

Ermias, T. and Addisu, T. 2013. Integrated management of chocolate spot (Botrytis fabae Sard.) of faba bean (Vicia faba L.) at highlands of Bale, southeastern Ethiopia. Research Journal of Agricultural and Environmental Management 2(1):11-14.

FAO. 2019. FAOSTAT Database http:// www.fao.org/faostat/en/\#data/QC. Accessed on 10 May 2019.

FAO. 2007. Land evaluation towards a revised framework. Food and Agriculture Organization of the United Nations, Rome, Italy.

FAO. 1993.Guidelines for Land-Use Planning. FAO Development Series 1. FAO, Rome, Italy.

FAO. 1984. Land evaluation: Part three. Crop environmental requirements. Assistance to land use planning. Ministry of Agriculture, Addis Ababa, Ethiopia.

FAO. 1976. A framework for land evaluation: Soils Bulletin: 32, Food and Agriculture Organization of the United Nations, Rome, Italy.

Hawtin, G.C. and Hebblewate, P.D. 1983. Background and history of faba bean production. pp. 1 - 22. In: The faba bean 
(Vicia faba L.). Hebblewate, P.D. (Ed.). Butterworth's, London.

IBC (Institute of Biodiversity Conservation). 2007. Country Report on the State of PGRFA to FAO. Addis Ababa, Ethiopia.

ISRIC (International Soil Reference Information Center). 2015. www.soilgrids. org, Accessed on 2 July 2016.

Jarso, M. and Keneni, G. 2006. Vicia faba L. pp. pp. 195-199. In: Brink, M. and Belay, G. (Eds). Plant resources of Tropical Africa 1. Cereals and pulses. PROTA Foundation, Wageningen, Netherlands/Backhuys Publishers, Leiden, Netherlands/CTA, Wageningen, Netherlands.

Jarvis, A., Reuter, H.I., Nelson, A. and Guevara, E. 2008. Hole-filled SRTM for the Globe Version 4, available from the CGIAR-CSI SRTM 90m Database (http:// srtm.csi.cgiar.org accessed on May 2016).

Löw, F., Biradar, C., Dubovyk, O., Fliemann, E., Akramkhanov, A., Vallejo, A.N. and Waldner. F. 2018. Regional-scale monitoring of cropland intensity and productivity with multi-source satellite image time series. GIS Science \& Remote Sensing 55(4):539-567.

MoARD (Ministry of Agriculture and Rural Development). 2006. Crop variety Register. Issue No.9, Addis Ababa, Ethiopia.

MoARD (Ministry of Agriculture and Rural Development). 2008. Crop variety Register. Issue No.11, Addis Ababa, Ethiopia.

MoA (Ministry of Agriculture). 2010. Crop variety Register Issue No. 13, Addis Ababa, Ethiopia.

MoA (Ministry of Agriculture). 2014. Crop variety Register Issue No. 17, Addis Ababa, Ethiopia.

Mokarram, M., Rangzan, K., Moezzi, A. and Baninemeh, J. 2010. Land suitability evaluation for wheat cultivation by fuzzy theory approach as compared with parametric method. The International Archives of the Photogrammetry, Remote Sensing and Spatial Information Sciences - ISPRS Archives 38(2):140-145.
NAIA(National Agricultural Inputs Authority). 2003. Crop variety Register Issue No.5, Addis Ababa, Ethiopia.

Nigussie, D. 2018. GIS-based land suitability mapping for legume crops technology targeting and scaling-up. Ethiopian Journal of Agricultural Science 6(1):179-198.

Nigussie, D. 2014. Land suitability atlas for selected crops of Ethiopia. Addis Ababa, Ethiopia: EIAR.

Perveen, M.F., Nagasawa, R., Uddin, M.I. and Delowar, H.K. 2007. Crop-land suitability analysis using a multi-criteria evaluation and GIS approach. University of California, Berkeley, USA: ISDE (International Symposium on Digital Earth).

Pietrzak, W., Kawa-Rygielska, J., Król, B., Lennartsson, P. R. and Taherzadeh, M.J. 2016. Ethanol, feed components and fungal biomass production from field bean (Vicia faba var. equina) seeds in an integrated process. Bioresource Technology 216:6976. doi: 10.1016/j.biortech.2016.05.055

Saaty, R.W. 1987. The analytic hierarchy process - What it is and how it is used. Mathematical Modelling 9 (3-5): 161-176.

Singha, C. and Swain, K.C. 2016. Land suitability evaluation criteria for agricultural crop selection: A review. Agricultural Reviews 37(2):125-132.

Sys. C., Ranst, V., Debaveye, J. and Beernaert, F. 1993. Land evaluation Part III, Crop requirements. Agricultural Publication No. 7, Brussels, Belgium.

Tafere, M., Tadesse, D. and Yigzaw, D. 2012. Participatory varietal selection of faba bean (Vicia faba L.) for yield and yield components in Dabat district, Ethiopia. Wudpecker Journal of Agricultural Research 1(7): 270-274

WBISPP (Woody Biomass Inventory and Strategic Planning Project).2004. Woody Biomass Inventory and Strategic Planning Project database. Addis Ababa, Ethiopia: MoA. 